\title{
Financial and feasibility implications of the treatment of hepatitis $C$ virus in Italy: scenarios and perspectives
}

This article was published in the following Dove Press journal:

ClinicoEconomics and Outcomes Research

8 August 2016

Number of times this article has been viewed

\author{
Davide Croce ${ }^{1,2}$ \\ Marzia Bonfanti' \\ Umberto Restelli ${ }^{1,2}$ \\ 'Center for Research on Health \\ Economics, Social and Health Care \\ Management, Università Cattaneo, \\ Castellanza, Italy; ${ }^{2}$ School of Public \\ Health, Faculty of Health Sciences, \\ University of the Witwatersrand, \\ Johannesburg, South Africa
}

Background: Hepatitis $\mathrm{C}$ virus (HCV) affects an estimated number of people between 130 million and 210 million worldwide. In the next few years, the Italian National Health Service will face a growing trend of patients requiring HCV antiviral treatments. The aim of the analysis was to estimate the time horizon in which it would be possible to treat $\mathrm{HCV}$-infected patients and the related direct medical costs (antiviral treatment and monitoring activities) from the Italian National Health Service point of view.

Methodology: In order to estimate the number of HCV-infected patients in Italy, we considered a top-down (considering published data) and a bottom-up approach. The number of years needed for treatment and related direct costs were estimated through the development of a static deterministic model.

Results: The estimated number of $\mathrm{HCV}$-infected patients in Italy varies from 2.7 (estimated through a top-down approach) to 0.6 million (estimated through a bottom-up approach) and 0.3 million (measured through a bottom-up approach). Considering the last two scenarios and the use of interferon-free therapies for 50,000 patients per year, treatment for HCV-infected patients could be at a cost of $€ 13.7$ billion and $€ 7.0$ billion by 2030 and 2023 , respectively.

Conclusion: The treatment for HCV-infected patients in Italy is a challenging target for the financial implications of patient care. HCV infection could be controlled or eliminated in a 10- to 15-year time horizon. The cost of treatment can hardly be dealt with using the traditional economic tools but should be faced through multiyear investments, as health benefits are expected in the long period. National Health Service stakeholders (industry, government, insurance, and also patients) will have to identify suitable financial instruments to face the new expenditure required.

Keywords: sustainability, financial disease scenario, budget impact model

\section{Background Epidemiology}

Hepatitis $\mathrm{C}$ virus (HCV) is an asymptomatic disease and, as such, is treated mainly at an advanced stage. ${ }^{1}$ However, the clinical evolution of $\mathrm{HCV}$ infection in the medium and long terms may lead to liver compensated and decompensated cirrhosis, hepatocellular carcinoma (HCC), liver transplant, and eventually to death. Among the patients who suffer from HCV infection, in fact, $>90 \%$ become chronic carriers, among them $65 \%-95 \%$ develop chronic liver disease, and in $10 \%-30 \%$ of the cases, an evolution into cirrhosis is observed within $25-30$ years. ${ }^{2}$ Cirrhotic subjects have a yearly probability between $1 \%$ and $3 \%$ to develop HCC. ${ }^{3}$
Correspondence: Davide Croce

Center for Research on Health Economics, Social and Health Care Management, Università Cattaneo, Corso Matteotti 22, 21053 Castellanza VA, Italy $\mathrm{Tel}+390331572424$ Fax +390331572513 Email dcroce@liuc.it 
$\mathrm{HCV}$ affects an estimated number between 130 million and 210 million people worldwide. ${ }^{4}$ According to the findings of a study conducted in 2014 by the European Centre for Disease Prevention and Control, Italy has the highest number of HCV-positive patients in Europe and the highest rate of death from cirrhosis and HCC. ${ }^{5}$ The significant epidemiological impact of the disease will lead the Italian National Health Service (NHS) in the next 5-10 years to offer an increasing number of HCV-related health services to a growing number of patients. ${ }^{2}$

\section{Management of chronic HCV}

In the last 2 years, several new drugs have been authorized in the European market, with a therapy duration of few weeks, with less side effects than the first-generation protease inhibitors and with a high percentage of sustained virological response, defined as "undetectable HCV RNA 12 weeks or 24 weeks after treatment completion". ${ }^{6}$ In 2015, the European Association for the Study of Liver published therapeutic recommendations for the treatment of $\mathrm{HCV}$ infection, divided by HCV genotype. ${ }^{6}$

In addition to the aforementioned treatment recommendations, in Italy further management tools were introduced in the regulation of drug treatment for HCV: a centralized log monitoring, the identification of $\mathrm{HCV}$ antiviral treatment prescribing centers by the Regional Health Services, and the identification of seven criteria by the Italian Medicines Agency (AIFA) to prioritize patients to be treated, and select the most appropriate antiviral therapy to be administered. ${ }^{7}$ In the Italian context, all the health costs for the patients admitted to the pharmacological therapy for HCV are fully covered by the Regional Health Service.

At a regional level (the public payor), the management tools introduced for the disease are the identification of reference treatment centers (373 in Italy), setting of annual budgets (different in each region considering the estimated number of target patients), and the collection of bottom-up clinical information of each treated patient.

\section{The cost of pathology}

$\mathrm{HCV}$ is not only a considerable social burden but also an important chapter of NHS spending. In the next few years, the Italian NHS will face a growing trend of patients requiring $\mathrm{HCV}$ antiviral treatments (around 30,000 patients started antiviral treatment in 2015). ${ }^{8}$ In terms of economic weight, new antiviral drugs for the treatment of HCV have increased their impact on the total NHS financing up to $0.45 \%$ in 2015 (considering the $€ 0.5$ billion allocated in 2015 for purchasing HCV antiviral treatments over the Italian NHS budget of $€ 109.7$ billion).
The literature highlights how treatment costs increase with the degree of severity of patients' condition: ${ }^{9,10}$ per patient direct and indirect costs are mainly absorbed by cirrhotic patients and those affected by advanced forms of liver disease. ${ }^{10}$ In the same study, the annual direct and indirect costs of the disease in Italy are estimated to be $€ 418$ million and $€ 643$ million, respectively, reaching a total of $€ 1.061$ billion. The total costs for chronic HCV patients are $€ 256$ million, cirrhotic patients $€ 560$ million, patients affected with HCC $€ 50$ million, and patients admitted to liver transplant $€ 48$ million, and costs due to patients' death equal to $€ 146$ million.

Vietri et al (2013) ${ }^{11}$ assessed the indirect and direct costs of the pathology in 2010, comparing self-reported outcomes (absenteeism and presenteeism) and use of resources in a sample of $286 \mathrm{HCV}$-infected patients from five European countries (Italy, France, Germany, the United Kingdom, and Spain) with a matched control sample of patients with similar demographic and health characteristics. The results of the analysis for the Italian environment show higher working and activity impairments and health care use in the HCV-infected group compared with the control group. The indirect mean annual costs per patient were $€ 7,532.54$ in $\mathrm{HCV}$-infected patients vs $€ 4,576.43$ in the control group ( $P=0.002$ ), and the direct mean annual costs per patient (physician visits, emergency room visits, and hospitalizations) were $€ 1,147.06$ and $€ 652.07(P<0.001)$ in $\mathrm{HCV}$-infected patients and control group, respectively.

In 2015, the research group of the University of Tor Vergata, Rome, published the first Italian pharmacoeconomic model that describes the epidemiological and economic burden (both direct and indirect medical costs) that $\mathrm{HCV}$ is expected to have up to 2020, 2030, and 2040 on the Italian NHS assuming the use of the first-generation protease inhibitors, boceprevir and telaprevir, of peginterferon-alfa + ribavirin and the second-generation treatments. ${ }^{12}$ They also estimated that there will be a reduction of $>156,000 \mathrm{HCV}-$ related events and a reduction in health care costs between $€ 13,000$ and $€ 18,000$ per treated patient in a 10 - to 30 -year time horizon.

\section{Objectives}

Considering the lack of a structured study at a national level to assess the impact of the second-generation pharmacological treatments for HCV infection in Italy, the aim of the analysis presented was to estimate the total cost of the treatment and the related parameters (eg, time horizon for treatment period and NHS treatment capacity) referring to the most 
recent treatment recommendations ${ }^{6}$ by developing a static deterministic model and using both top-down and bottom-up approaches to identify the number of $\mathrm{HCV}$-infected patients. The point of view considered is that of the Italian NHS.

\section{Methodology Epidemiology}

The number of HCV-infected patients in Italy was estimated using two different approaches. First, a top-down approach

Table I HCV prevalence, genotype distribution, and fibrosis stage distribution among the Italian HCV-infected population

\begin{tabular}{llll}
\hline Identification category & Partition & \% value & Reference \\
\hline Prevalence (age-adjusted & North & 1.6 & 13 \\
analysis) & Central & 6.1 & \\
Genotype & Southern & 7.3 & \\
& $\mathrm{I}$ & 52.4 & 14 \\
& 2 & 26.6 & \\
& 3 & 9.8 & \\
Fibrosis stage & 4 & 10.5 & \\
& 5 & 0.7 & \\
& F0-FI & 42 & 15 \\
& F2 & 15 & \\
& F3 & 12 & \\
\hline
\end{tabular}

Abbreviation: $\mathrm{HCV}$, hepatitis $\mathrm{C}$ virus. was used considering the published data related to the Italian context in terms of regional prevalence, ${ }^{13}$ genotype distribution, ${ }^{14}$ and fibrosis stage ${ }^{15}$ (Table 1).

The combination of the data referred to prevalence, genotypes, and liver fibrosis stages distribution among the Italian population (considering the Italian Resident Population on January 1, 2015) ${ }^{16}$ (Table 1) leads to the regional estimation presented in Table 2. The total number of HCV-infected subjects in Italy using a top-down approach is estimated to be 2,688,444.

Second, a bottom-up approach was also used to estimate the emerged cases of HCV infection in Italy, identified through data available in literature that were collected thriough the records of the Italian NHS. The number of patients with an exemption from copayment due to HCV condition (which in the Italian NHS is certified by local health authorities) is 308,624. ${ }^{17}$ Further patients should be included: 20,640 HIV coinfected patients (identified through the Italian Cohort Naive Antiretrovirals) ${ }^{17}$ and 3,860 estimated patients in prison detention (number of persons in prison detention on December 31, 2015, and HCV prevalence among the prisoners). ${ }^{18,19}$ Moreover, the number of $\mathrm{HCV}$-infected patients, aware of their condition and who benefit from low-income exemption from copayment (total exemption from all copayments in the NHS than for only copayment for HCV-related treatments,

Table 2 Regional estimation of the number of hepatitis $C$ virus-infected patients divided by genotype and fibrosis stage using a topdown approach

\begin{tabular}{|c|c|c|c|c|c|c|c|c|c|c|c|}
\hline \multicolumn{12}{|l|}{ Top-down approach } \\
\hline Region & $\begin{array}{l}\text { GI } \\
\text { F0-F2 }\end{array}$ & $\begin{array}{l}\text { G I } \\
\text { F3-F4 }\end{array}$ & $\begin{array}{l}\text { G2 } \\
\text { F0-F2 }\end{array}$ & $\begin{array}{l}\text { G2 } \\
\text { F3-F4 }\end{array}$ & $\begin{array}{l}\text { G3 } \\
\text { F0-F2 }\end{array}$ & $\begin{array}{l}\text { G3 } \\
\text { F3-F4 }\end{array}$ & $\begin{array}{l}\text { G4 } \\
\text { F0-F2 }\end{array}$ & $\begin{array}{l}\text { G4 } \\
\text { F3-F4 }\end{array}$ & $\begin{array}{l}\text { G5 } \\
\text { F0-F2 }\end{array}$ & $\begin{array}{l}\text { G5 } \\
\text { F3-F4 }\end{array}$ & Total \\
\hline Piemonte $^{\mathrm{a}}$ & 21,144 & $|5,95|$ & 10,734 & 8,097 & 3,955 & 2,983 & 4,237 & 3,196 & 283 & 213 & 70,791 \\
\hline Valle d'Aosta ${ }^{\mathrm{a}}$ & 613 & 463 & 311 & 235 & 115 & 86 & 123 & 93 & 8 & 6 & 2,053 \\
\hline Lombardia $^{a}$ & 47,801 & 36,061 & 24,266 & 18,305 & 8,940 & 6,744 & 9,578 & 7,226 & 638 & 482 & 160,042 \\
\hline Trentino-Alto Adige ${ }^{\mathrm{a}}$ & 5,046 & 3,807 & 2,562 & 1,932 & 944 & 712 & $\mathrm{I}, 0 \mathrm{II}$ & 763 & 67 & 51 & 16,895 \\
\hline Veneto $^{a}$ & 23,548 & 17,765 & 11,954 & 9,018 & 4,404 & 3,322 & 4,718 & 3,560 & 315 & 237 & 78,842 \\
\hline Friuli-Venezia Giulia ${ }^{a}$ & 5,864 & 4,424 & 2,977 & 2,246 & $\mathrm{I}, 097$ & 827 & $\mathrm{I}, 175$ & 887 & 78 & 59 & 19,634 \\
\hline Liguria $^{a}$ & 7,566 & 5,708 & 3,841 & 2,897 & 1,415 & 1,068 & 1,516 & $\mathrm{I}, \mathrm{I} 44$ & 101 & 76 & 25,332 \\
\hline Emilia-Romagna $^{a}$ & 21,268 & 16,045 & 10,796 & 8,145 & 3,977 & 3,001 & 4,262 & 3,215 & 284 & 214 & 71,208 \\
\hline Toscana $^{\mathrm{b}}$ & 68,372 & 51,578 & 34,708 & 26,183 & 12,787 & 9,646 & $|3,70|$ & 10,335 & 913 & 689 & 228,912 \\
\hline Umbriab $^{\mathrm{b}}$ & 16,302 & 12,298 & 8,275 & 6,243 & 3,049 & 2,300 & 3,267 & 2,464 & 218 & 164 & 54,580 \\
\hline Marche $^{b}$ & 28,255 & 21,315 & 14,343 & 10,820 & 5,284 & 3,987 & 5,662 & 4,271 & 377 & 285 & 94,599 \\
\hline Laziob & 107,357 & 80,988 & 54,498 & 41,112 & 20,078 & 15,147 & 21,512 & 16,229 & $\mathrm{I}, 434$ & 1,082 & 359,438 \\
\hline Abruzzo $^{c}$ & 29,033 & 21,902 & 14,739 & II,II8 & 5,430 & 4,096 & 5,818 & 4,389 & 388 & 292 & 97,205 \\
\hline Molise $^{c}$ & 6,832 & 5,154 & 3,468 & 2,617 & $\mathrm{I}, 278$ & 964 & 1,369 & $\mathrm{I}, 033$ & 91 & 69 & 22,874 \\
\hline Campania $^{c}$ & 127,803 & 96,412 & 64,877 & 48,942 & 23,902 & $|8,03|$ & 25,610 & 19,319 & $\mathrm{I}, 707$ & 1,288 & 427,892 \\
\hline Puglia $^{c}$ & 89,180 & 67,275 & $45,27 \mid$ & $34,|5|$ & 16,679 & 12,582 & 17,870 & $|3,48|$ & 1,191 & 899 & 298,578 \\
\hline Basilicata $^{c}$ & 12,573 & 9,484 & 6,382 & 4,815 & 2,351 & $\mathrm{I}, 774$ & 2,519 & $|, 90|$ & 168 & 127 & 42,093 \\
\hline Calabria $^{c}$ & 43,098 & 32,512 & 21,878 & 16,504 & 8,060 & 6,081 & 8,636 & 6,515 & 576 & 434 & 144,294 \\
\hline Sicilia $^{c}$ & I I I,026 & 83,756 & 56,361 & 42,517 & 20,765 & 15,664 & 22,248 & 16,783 & 1,483 & 1,119 & 371,722 \\
\hline Sardegna ${ }^{b}$ & 30,304 & 22,861 & 15,383 & 11,605 & 5,668 & 4,275 & 6,072 & 4,581 & 405 & 305 & 101,460 \\
\hline Italy & 802,987 & 605,758 & 407,623 & 307,503 & 150,177 & 113,290 & 160,904 & 121,383 & 10,727 & 8,092 & $2,688,444$ \\
\hline
\end{tabular}

Notes: Prevalence data: aNorth; ${ }^{\text {bCentral; ' }}$ South. GI-G5 are genotype distributions. F0-F4 are fibrosis stages. 
which is more valuable for patients) should be estimated. In Italy, according to the Ministry of Health data, 6,930,000 patients are exempt from copayment because of low income (46.2\% of the total exemptions from copayment for any reason in Italy). ${ }^{20}$ Among them, using the national age-adjusted prevalence rate of $4.4 \%,{ }^{13}$ further $304,920 \mathrm{HCV}$-infected patients are estimated. Therefore, the total number of patients with a diagnosis of HCV infection in Italy is estimated to be within a range from 329,264 to 613,124 .

Comparing the results of bottom-up and top-down analyses, we can state that the number of $\mathrm{HCV}$-infected patients in Italy is between 0.3 million and 2.7 million. Considering the number of reference treatment centers activated in Italy at a regional level, ${ }^{21}$ the average number of patients to be treated per center is estimated to be 7.208 for the 2.7 million prevalence scenario, 1.711 for the 0.6 million prevalence scenario, and 883 for the 0.3 million prevalence scenario.

\section{Economic analysis}

Starting from prevalence data and the European antiviral treatment guidelines (considering the information available on pharmaceutical companies' cost-volume agreements), we estimated the total direct medical costs that Italian NHS should tackle in order to eliminate the virus in terms of direct medical costs related to antiviral treatment and monitoring activities (treating the entire infected population regardless of the fibrosis stage), developing a static deterministic model to assess the time period in which it would be possible to treat these patients, until reaching a prevalence below $100 \mathrm{HCV}$ infections.

At time 0, patients are distributed among health states, characterized by different stages of evolution of the pathology (ie, fibrosis stages from 0 to 4 , decompensated cirrhosis, HCC, and patients eligible for liver transplant). The patient distribution at time 0 is presented in Table 3. Mühlberger et al (2009) $)^{22}$ reported that in Italy, every year, 1,050 patients enter the model in fibrosis stage 0 (F0), considering a mean incidence of 1.75 cases per 100,000 inhabitants. Each year, patients may change their health state (F0, F1, F2, F3, F4, decompensated cirrhosis, HCC, transplant year 1, transplant year $2+$, and death) using the following rates of transition: from F0 to F1, 0.077; from F1 to F2, 0.092; from F2 to F3, 0.145; from F3 to F4, 0.116; from F4 to decompensated cirrhosis, 0.039; from F4 to HCC, 0.014; from decompensated cirrhosis to $\mathrm{HCC}, 0.014$; from decompensated cirrhosis to liver transplant, 0.030; from HCC to liver transplant, 0.030; from decompensated cirrhosis to death, 0.130; from $\mathrm{HCC}$ to death, 0.430; from liver transplant (year 1) to death, 0.210; from liver transplant (year 2 and following years), 0.057.23-25
Table $3 \mathrm{HCV}$-infected patient distribution in year 0

\begin{tabular}{|c|c|c|c|c|}
\hline \multirow[t]{2}{*}{ Health state } & \multicolumn{3}{|c|}{ Number of patients } & \multirow[t]{2}{*}{ Source } \\
\hline & 329,264 & 613,124 & $2,688,444$ & \\
\hline$\overline{\mathrm{F} 0}$ & 69,145 & 128,756 & 564,573 & Calculated \\
\hline $\mathrm{FI}$ & 69,145 & 128,756 & 564,573 & considering data \\
\hline F2 & 49,390 & 91,969 & 403,267 & from reference 15 \\
\hline F3 & 39,512 & 73,575 & 322,613 & \\
\hline $\mathrm{F} 4$ & 66,644 & $|32,64|$ & 615,153 & \\
\hline $\begin{array}{l}\text { Decompensated } \\
\text { cirrhosis }\end{array}$ & 22,215 & 44,214 & 205,05 I & $\begin{array}{l}\text { Calculated } \\
\text { considering a 3:I } \\
\text { ratio between } \\
\text { compensated } \\
\text { cirrhosis and } \\
\text { decompensated } \\
\text { cirrhosis }^{30}\end{array}$ \\
\hline $\mathrm{HCC}$ & 12,850 & & & $\begin{array}{l}\text { Calculated } \\
\text { considering the } \\
\text { number of } \mathrm{HCCs} \\
\text { due to } \mathrm{HCV}, 60 \%,{ }^{31} \\
\text { from the } 35,447 \\
\text { patients with } \mathrm{HCC} \\
\text { in Italy in } 2015^{32}\end{array}$ \\
\hline Liver transplant & 364 & & & $\begin{array}{l}\text { Calculated } \\
\text { considering } \\
\text { the } 34.5 \% \text { liver } \\
\text { transplants due } \\
\text { to } \mathrm{HCV}^{33} \text { among } \\
\text { the } 1,056 \text { liver } \\
\text { transplants in Italy } \\
\text { in } 2014^{34}\end{array}$ \\
\hline
\end{tabular}

Note: F0-F4 are fibrosis stages.

Abbreviations: $\mathrm{HCC}$, hepatocellular carcinoma; $\mathrm{HCV}$, hepatitis $\mathrm{C}$ virus.

The distribution of patients in different health states in the baseline scenario (no patients treated) is compared with four different scenarios in which a fixed number of patients is treated with antiviral therapies in each yearly cycle: 25,000 ; 50,000; 75,000; and 100,000. Considering the number of reference treatment centers that were already authorized in Italy and the maximum number of weeks per treatment (24 weeks), we estimated an average number of patients to be managed by each center at the same time to be between 34 and 134 patients.

In the model, patients are treated starting from those associated with worst health states (eligible for a liver transplant the same year, HCC, decompensated cirrhosis, F4, F3, F2, $\mathrm{F} 1$, and F0). Based on the effectiveness of each antiviral treatment (as reported in Table 4), patients may reach a sustained virological response and exit the model or remain in the same health state and be retreated the following year.

The direct medical costs for treated patients include those of the antiviral treatment and of patient monitoring (ie, specialist visits, HCV-RNA test, alanine aminotransferase test, prothrombin time/international normalize ratio test, 
Table $4 \mathrm{HCV}$ therapies considered in the model and related effectiveness parameters

\begin{tabular}{|c|c|c|c|c|c|c|c|}
\hline \multirow[t]{2}{*}{ Scenario } & \multirow[t]{2}{*}{ Genotype } & \multicolumn{3}{|c|}{ Antiviral treatment for noncirrhotic patients } & \multicolumn{3}{|c|}{ Antiviral treatment for cirrhotic patients } \\
\hline & & Antiviral therapy & SVR I 2 & Source & Antiviral therapy & SVR I2 & Source \\
\hline \multirow{5}{*}{$\begin{array}{l}\text { All } \\
\text { treatments } \\
\text { available }\end{array}$} & Genotype I & Peg-IFN- $\alpha+$ RBV + SOF for 12 weeks & $89.38 \%$ a,* & 35 & Peg-IFN- $\alpha+$ RBV + SOF for 12 weeks & $79.63 \%$ b & 35 \\
\hline & Genotype 2 & SOF + RBV for 12 weeks & $97.14 \%$ c,* & 35 & Peg-IFN- $\alpha+$ RBV + SOF for 12 weeks & $96.00 \%$ d, $*$ & 36 \\
\hline & Genotype 3 & Peg-IFN- $\alpha+$ RBV + SOF for 12 weeks & $90.00 \%$ e & 37 & Peg-IFN- $\alpha+$ RBV + SOF for 12 weeks & $87.93 \%$ f & 38 \\
\hline & Genotype 4 & $\mathrm{OMB} / \mathrm{PAR} / \mathrm{r}+\mathrm{RBV}$ for 12 weeks & $100.00 \%$ & 39 & $\mathrm{OMB} / \mathrm{PAR} / \mathrm{r}+\mathrm{RBV}$ for 12 weeks & $100.00 \%$ \% $*$ & 39 \\
\hline & Genotype 5 & Peg-IFN- $\alpha+$ RBV + SOF for 12 weeks & $97.14 \% \mathrm{~h}, *$ & 35 & Peg-IFN- $\alpha+$ RBV + SOF for 12 weeks & $79.63 \%$ & 35 \\
\hline \multirow{5}{*}{$\begin{array}{l}\text { Only } \\
\text { interferon } \\
\text {-free } \\
\text { treatments }\end{array}$} & Genotype I & SOF + LDV for 8-12 weeks & $98.60 \%$, $*$ & 40 & SOF + LDV + RBV for 24 weeks & $99.08 \%$ i.* & 40 \\
\hline & Genotype 2 & SOF + RBV for 12 weeks & $97.14 \%$ c,* & 35 & SOF + RBV for 20 weeks & $97.14 \%$ c,* & 35 \\
\hline & Genotype 3 & SOF + RBV for 24 weeks & $86.51 \% \mathrm{k}$ & 38 & SOF + DCV + RBV for 24 weeks & $57.89 \%$ & 41 \\
\hline & Genotype 4 & $\mathrm{OMB} / \mathrm{PAR} / \mathrm{r}+\mathrm{RBV}$ for 12 weeks & $100.00 \%$ & 39 & $\mathrm{OMB} / \mathrm{PAR} / \mathrm{r}+\mathrm{RBV}$ for 12 weeks & $100.00 \%, *$ & 39 \\
\hline & Genotype 5 & SOF + LDV for 12 weeks & $98.60 \%$ i,* & 40 & SOF + LDV + RBV for 24 weeks & $99.08 \%$ j,* & 40 \\
\hline
\end{tabular}

Notes: a Genotype I naïve cirrhotic and noncirrhotic patients. ${ }^{\mathrm{b}}$ Genotype I, 4, 5, and 6 naïve cirrhotic patients. ${ }^{\mathrm{C}} \mathrm{Genotype} 2$ naïve cirrhotic and noncirrhotic patients.

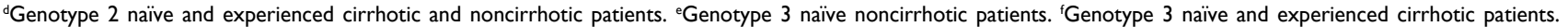
${ }^{8}$ Genotype 4 naïve noncirrhotic patients. 'Genotype 4, 5, and 6 naïve cirrhotic and noncirrhotic patients. 'Genotype I naïve cirrhotic and noncirrhotic patients. 'Genotype I naïve cirrhotic and noncirrhotic patients. ${ }^{k} G$ enotype 3 naïve and experienced noncirrhotic patients. 'Genotype 3 naïve cirrhotic patients. ${ }^{*} D u e$ to lack of published data concerning SVR at 12 weeks in the target population, the effectiveness values considered for noncirrhotic patients might be underestimated and the effectiveness values considered for cirrhotic patients might be overestimated.

Abbreviations: DCV, Daclatasvir; HCV, hepatitis C virus; LDV, Ledipasvir; OMB, Ombitasvir; PAR, Paritaprevir; Peg-IFN- $\alpha$ : peginterferon-alfa; r, Ritonavir; RBV, Ribavirin; SOF, Sofosbuvir; SVR, sustained virological response.

bilirubin test, and leukocyte count). Information concerning patient monitoring activities reflect the real clinical practice of two hospitals in Lombardy and Veneto regions, which are collected by interviewing key opinion leaders, and lead to a mean monitoring cost of $€ 702$ per treatment.

The cost of antiviral treatment was calculated considering the recommendations of the European Association for the Study of the Liver (2015), ${ }^{6}$ divided by genotype and fibrosis stage, starting from the information available from the Italian Ministry of Health Official Gazette and official documentation. The costs related to each treatment recommended by the European Association for the Study of the Liver were then considered to select the less expensive antiviral therapy for each genotype and fibrosis stage (ie, genotype 1-infected patients with F0, F1, F2, F3, and F4 stages; genotype 2-infected patients with F0, F1, F2, F3, and F4 stages; etc). Two hypotheses were then considered: the possibility to use peginterferon within treatments and the sole use of interferonfree therapies.

The effectiveness parameters considered in the model, in terms of sustained virological response at 12 weeks, are those available in literature associated with the therapies considered per each genotype. The therapies within the two scenarios and the effectiveness parameters considered are reported in Table 4.

Effectiveness data were not available for all the directacting antiviral, genotype, and fibrosis conditions, therefore, overall effectiveness data for the unclustered patient population were considered in those cases. During the Social Affairs Commission of the Italian Parliament audition on November 16, 2015, the managing director of AIFA stated
Table 5 Cost of antiviral treatment considered in the analysis

\begin{tabular}{|c|c|c|}
\hline Antiviral drug & $\begin{array}{l}\text { Cost per treatment, } \\
€ \text { (VAT inclusive) }\end{array}$ & Source \\
\hline Daclatasvir & 18,700 & 42 \\
\hline Ombitasvir/Paritaprevir/ & 16,353 & Assumption \\
\hline \multicolumn{3}{|l|}{ Ritonavir } \\
\hline Ombitasvir/Paritaprevir/ & 19,987 & Assumption \\
\hline \multicolumn{3}{|l|}{ Ritonavir + Dasabuvir } \\
\hline Peginterferon-alfa ${ }^{\wedge}$ & 186.1 & 43 \\
\hline Ribavirine $^{\wedge}$ & 84.1 & 44 \\
\hline Simeprevir* & 19,800 & 45 \\
\hline Sofosbuvir & 16,353 & Assumption \\
\hline Sofosbuvir + Ledipasvir & 19,987 & Assumption \\
\hline
\end{tabular}

Notes: ${ }^{\wedge}$ Cost per week. *Cost of a 12-week treatment.

Abbreviation: VAT, value-added tax.

that price-volume agreement for Sofosbuvir considered a price of treatment of $€ 750$ million for 50,000 patients ( $€ 15,000$ per treatment), with lower steps, down to $€ 4,000$ per treatment. ${ }^{26}$ Considering the hypothetical cost batches, from $€ 37,000$ to $€ 4,000$, the mean cost per treatment of Sofosbuvir was estimated to be $€ 16,353$ (value-added tax inclusive). The cost of Sofosbuvir + Ledipasvir was considered to be $111.11 \%$ of the cost of Sofosbuvir as in the Italian Official Gazette documents, ${ }^{27,28}$ equal to $€ 19,987$ (value-added tax inclusive).

Due to lack of data concerning the price-volume agreement for Ombitasvir/Paritaprevir/Ritonavir and Ombitasvir/ Paritaprevir/Ritonavir + Dasabuvir, and assuming it to be similar to the one described earlier, we considered the same price of Sofosbuvir and Sofosbuvir + Ledipasvir, respectively. The costs per treatment considered in the analysis, valueadded tax inclusive, are presented in Table 5. 


\section{Results}

\section{Economic analysis}

Considering the number of diagnosed HCV-infected patients emerged from the hypotheses presented in "Economic analysis" section (bottom-up assessment of 0.3 million patients, bottom-up estimation of 0.6 million patients, and top-down estimation of 2.7 million patients), it is possible to forecast the number of years required to treat the whole Italian HCV-infected population, starting from 2016. HCV treatments last for 8-12 weeks, up to 24 weeks, requiring a constant monitoring of patients during the whole curative process. In 2015, 30,000 HCV-infected patients were treated with antiviral treatments. Authorized referred centers have a higher capacity in terms of patients being treated yearly; therefore, different scenarios were considered in terms of number of annual treated patients: 25,$000 ; 50,000 ; 75,000$; and 100,000 .

In Table 6, we report the estimated direct medical costs for antiviral treatment of the whole Italian HCV-infected population in the three scenarios presented and the year in which $\mathrm{HCV}$ prevalence would fall below 100 infected patients. The estimation has a 35-year time horizon, up to 2050 .

The results of the strategy that consider the use of therapies with peginterferon-alfa lead to higher costs compared with the sole use of interferon-free antiviral therapies. This is due to the mean higher effectiveness of these treatments, leading to a lower number of retreatments. The 2.7 million $\mathrm{HCV}$-infected patients scenario considering a number of yearly treated patients below 100,000 lead to a lack of treatment for all $\mathrm{HCV}$-infected patients. In these scenarios, up to
2050, more than 0.16 million patients and up to 1.29 million patients would not have been treated with antiviral therapies.

Finally, in order to estimate the benefits deriving from the management of HCV infection, the number of deaths and the number of patients with HCCs and liver transplants due to $\mathrm{HCV}$ infection avoided due to treatments were estimated considering the most plausible hypothesis of prevalence and the number of treatments per year: 0.3 million and 0.6 million HCV-infected patients (derived from the bottom-up analysis) and 50,000 interferon-free treatments per year. The productivity condition (eg, human and structural resources) of the $\mathrm{HCV}$ antiviral treatments by authorized prescribing centers, in fact, could be enough to treat $\sim 50,000$ patients per year (with an estimated mean number of 67 patients to be managed per center at the same time). In order to deal with more patients, it would be necessary to activate further centers at a regional level.

Specifically, according to the aforementioned transition probabilities in the two scenarios $(0.3$ million and 0.6 million HCV-infected patients), the mean number of deaths avoided (compared with the do-nothing scenario) per year would be 3,518 and 7,657; the mean number of liver transplants avoided per year would be 606 and 1,220; and the mean number of HCCs avoided per year would be 1,013 and 2,411, respectively. Multiplying the annual average cost per patient affected by HCV-induced diseases (calculated by Marcellusi et al, 2015, ${ }^{10}$ and converted to 2015 cost level using the annual average consumer prices inflation rate as calculated by the International Monetary Fund ${ }^{29}$ by the number of years spent by the estimated population with HCC, by the total number of avoided transplants and deaths, we estimated the direct

Table 6 Estimated direct medical costs (antiviral therapy and monitoring activities) to treat the whole HCV-infected Italian population and year in which HCV prevalence would fall below 100 infected patients (up to 2050)

\begin{tabular}{|c|c|c|c|c|c|}
\hline \multirow{2}{*}{$\begin{array}{l}\text { Estimated HCV- } \\
\text { infected patients }\end{array}$} & \multirow{2}{*}{$\begin{array}{l}\text { Patients } \\
\text { treated } \\
\text { per year }\end{array}$} & \multicolumn{2}{|c|}{ Sole use of interferon-free therapies } & \multicolumn{2}{|c|}{ Use of interferon and interferon-free therapies } \\
\hline & & $\begin{array}{l}\text { Year in which prevalence } \\
\text { fall below } 100 \text { infected } \\
\text { patients }\end{array}$ & $\begin{array}{l}\text { Cost to treat the } \\
\text { whole population } \\
\text { (thousands of } € \text { ) }\end{array}$ & $\begin{array}{l}\text { Year in which prevalence } \\
\text { fall below } 100 \text { infected } \\
\text { patients }\end{array}$ & $\begin{array}{l}\text { Cost to treat the } \\
\text { whole population } \\
\text { (thousands of } € \text { ) }\end{array}$ \\
\hline \multirow[t]{4}{*}{0.3 million } & 25,000 & 2030 & $7,177,964$ & 2032 & $7,624,657$ \\
\hline & 50,000 & 2023 & $6,980,742$ & 2025 & $7,331,094$ \\
\hline & 75,000 & 2021 & $6,918,47 \mid$ & 2023 & $7,198,620$ \\
\hline & 100,000 & 2020 & $6,896,528$ & 2022 & $7,115,776$ \\
\hline \multirow[t]{4}{*}{0.6 million } & 25,000 & 2044 & $14,343,430$ & 2046 & $15,4 \mid 8,509$ \\
\hline & 50,000 & 2030 & $13,742,639$ & 2032 & $14,563,554$ \\
\hline & 75,000 & 2025 & $13,565,065$ & 2027 & $14,280,134$ \\
\hline & 100,000 & 2023 & $13,484,796$ & 2025 & $|4| 23,,05 \mid$ \\
\hline \multirow[t]{4}{*}{2.7 million } & 25,000 & $2050^{\mathrm{a}}$ & $19,434,487$ & $2050^{b}$ & $19,373,070$ \\
\hline & 50,000 & $2050^{c}$ & $38,868,973$ & $2050^{d}$ & $38,746,140$ \\
\hline & 75,000 & $2050^{\mathrm{e}}$ & $57,145,868$ & $2050^{f}$ & $57,682,573$ \\
\hline & 100,000 & 2044 & $59,151,269$ & 2048 & $63,639,349$ \\
\hline
\end{tabular}

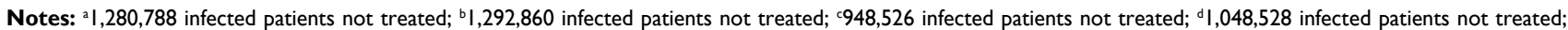
e 155,140 infected patients not treated; 3339,839 infected patients not treated.

Abbreviation: $\mathrm{HCV}$, hepatitis $\mathrm{C}$ virus. 
and indirect costs saved due to antiviral treatments in the 0.3 million $\mathrm{HCV}$-infected patients scenario to be equal to $€ 4.21$ billion in 8 years (direct costs of $€ 0.14$ billion and indirect costs of $€ 4.07$ billion), and in the 0.6 million $\mathrm{HCV}$-infected patients scenario equal to $€ 25.20$ billion in 15 years (direct costs of $€ 0.51$ billion and indirect costs of $€ 24.69$ billion).

\section{Discussion}

The estimation of the number of $\mathrm{HCV}$-infected patients in Italy shows a high spread between the top-down and bottomup approaches, with a difference of around 2.4 million patients, and it is a relevant health problem in the Italian population. Considering the lack of publications of prevalence studies conducted among a significant sample of patients and/or accurate sampling distributions, the authors consider the estimation through the bottom-up approach to be more reliable to identify the costs to be incurred by the Italian NHS.

Moreover, we consider the topic of eradication and disease control as highly challenging in the absence of an accurate monitoring program to diagnose $\mathrm{HCV}$ infection in patients unaware of the infection. Italy has a rate of incidence between 1 and 2.5 per 100,000 and a lack of increase of prevalent cases is probably already reached.

The cost of treatment could be difficult to reconcile with an annual budget for pharmaceutical treatment for the country in case of elimination/controlling of HCV infection considering the prevalence data presented earlier, with a yearly cost of treatment of $\sim € 1$ billion ( $€ 0.87$ billion and $€ 0.92$ billion) in the scenarios of bottom-up analysis (almost $5.5 \%$ of the total public financing for pharmaceutical treatments of the Italian NHS). HCV infection elimination requires a programmatic approach that probably fits better with a multiyear investment plan (treating all patients in a short-term horizon and paying the treatment costs in a medium-/long-term horizon).

Further research studies in this field should concentrate on the assessment of the prevalence and incidence of the pathology and on the effectiveness of antiviral treatments in different $\mathrm{HCV}$-infected patient subgroups (considering virus genotypes and degree of severity of the pathology).

The results of the analysis might be overestimated due to the use of a fixed incidence rate, which might decrease with the reduction of infected patients. Moreover, the model does not consider deaths due to other causes than HCV; therefore, long-term results might be overestimated.

The treatment of the highest number of patients per year would be important to avoid the progression of the pathology, with a relevant impact on the quality of life of patients and on avoided direct and indirect medical costs for the Italian NHS.
The opportunity to defer antiviral drug payment over a longer time period should be negotiated by the Italian Government with the pharmaceutical companies, to meet the objective of eliminating $\mathrm{HCV}$ with a sustainable multiyear payment schedule. The opportunity to control/eliminate the infection is in fact valuable, and the benefits for patients and for the Italian NHS would be maximized while treating the highest number of patients in a short-term horizon (considering the productive capacity of health care providers), deferring payments in the long-term. Health care sector in general and the pharmaceutical sector in particular will face further situations of this kind, for example, immunology discoveries, and then all the NHS stakeholders (industry, government and insurance, and also patients) will have to identify suitable financial instruments to face the new expenditure required.

The eradication of the disease in the 2.7 million infected people scenario would require a long time horizon, not compatible with the treatment of all patients, and also the capacity of treatment of the referring hospital centers could be questioned.

\section{Conclusion}

Italy has the highest prevalence of $\mathrm{HCV}$-infected patients in Europe and the highest rate of deaths from cirrhosis and $\mathrm{HCC}$, and the country needs a comprehensive approach to deal with this specific condition. The treatment of all HCVinfected patients in Italy (between 0.3 million and 2.7 million) is a challenging target for the financial implications of patient care, due to the number of specialist doctors needed and due to all other variables that affect the treatment of the disease.

In an environment with scarce resources, investments in health should be focused on those technologies that offer therapeutic efficacy rates high enough to allow the health services to amortize expenditures due to the savings induced by the treatments. In Italy, considering the two scenarios presented with 0.3 million and 0.6 million $\mathrm{HCV}$-infected patients, $\mathrm{HCV}$ infection could be eliminated/controlled in a 10 - to 15-year time horizon. In this framework, and in particular for chronic and potentially chronic diseases, a multidimensional approach such as Health Technology Assessment is strategic to support the evidence-based decision making. New highly expensive health technologies, both drugs and medical devices, will be available in different health care areas, determining the so-called competition between actions.

Finally, we observe that the relevant difference between patients conceivable through prevalence rates toward patients already aware of their $\mathrm{HCV}$ condition shows that the Italian 
NHS could face serious difficulties due to possible emergence of unaware HCV-infected patients due to antiviral treatment costs, population treatment time, and hospital production capacity.

\section{Disclosure}

The authors report no conflicts of interest in this work.

\section{References}

1. Alter MJ. Prevention of spread of hepatitis C. Hepatology. 2002; 36(5 Suppl 1):S93-S98.

2. Mennini FS, Marcellusi A, Andreoni M. Health policy model: longterm predictive results associated with the management of hepatitis C virus-induced diseases in Italy. Clinicoecon Outcomes Res. 2014;6: 303-310.

3. Fagiuoli S, Lucà MG, Magini G, De Giorgio M. Puntare sulla prevenzione delle epatiti come strategia per evitare che vi sia progressione dell'epatocarcinoma [Focusing on prevention of hepatitis as a strategy to ensure that there is progression of HCC]. Il Sole 24 Ore Sanità, giugno; 2013. Italian.

4. Lee MH, Yang HI, Yuan Y, L'Italien G, Chen CJ. Epidemiology and natural history of hepatitis C virus infection. World J Gastroenterol. 2014;20(28):9270-9280.

5. European Centre for Disease Prevention and Control. Technical Report Hepatitis B and C in the EU neighborhood: prevalence, burden of disease and screening policies; September 2010. Available from: http:// www.ecdc.europa.eu/en/publications/Publications/TER_100914_ Hep_B_C\%20_EU_neighbourhood.pdf. Accessed April 16, 2016.

6. European Association for the Study of the Liver. EASL recommendations on treatment of hepatitis C. J Hepatol. 2015;63(1):199-236.

7. Italian Medicines Agency (AIFA). Pubblicato il nuovo Algoritmo per la terapia dell'Epatite C cronica; 2015 [Published the new algorithm the Hepatitis C chronic therapy; 2015]. Available from: http://www.agenziafarmaco.gov.it/it/content/pubblicato-il-nuovo-algoritmo-la-terapiadell\%E2\%80\%99epatite-c-cronica. Accessed April 16, 2016. Italian.

8. Italian Medicines Agency (AIFA). Aggiornamento dati Registri AIFA DAAs 28 dicembre 2015 [Update Data Registers AIFA DAAs December 28, 2015]. Available from: http://www.agenziafarmaco. gov.it/sites/default/files/Aggiornamento_dati_Registri_AIFA_DAAs_ 28.12.2015.pdf. Accessed April 16, 2016. Italian.

9. Associazione Italiana per lo Studio del Fegato (AISF). Libro Bianco AISF 2011: Proposta per un piano nazionale per il controllo delle malattie epatiche. Definizione ambiti e possibili interventi; 2011 [AISF White Book 2011: Proposal for a national plan for disease control liver. Defining scopes and possible interventions; 2011]. Available from: http://www.webaisf.org/ media/13891/libro-bianco-aisf-2011.pdf. Accessed April 16, 2016. Italian.

10. Marcellusi A, Viti R, Capone A, Mennini FS. The economic burden of HCV-induced diseases in Italy. A probabilistic cost of illness model. Eur Rev Med Pharmacol Sci. 2015;19(9):1610-1620.

11. Vietri J, Prajapati G, El Khoury AC. The burden of hepatitis C in Europe from the patients' perspective: a survey in 5 countries. $B M C$ Gastroenterol. 2013;13:16.

12. Mennini FS, Marcellusi A, Viti R, Andreoni M. Disponibilità a pagare e innovazione: il caso dei farmaci anti-HCV nel Sistema Sanitario Italiano [Willingness to pay, and innovation: the case of anti-HCV drugs in the Italian health service]. GRHTA. 2015;2(2):69-77. Italian.

13. Ansaldi F, Bruzzone B, Salmaso S, et al. Different seroprevalence and molecular epidemiology patterns of hepatitis $\mathrm{C}$ virus infection in Italy. J Med Virol. 2005;76(3):327-332.

14. Marascio N, Matera G, Quirino A, et al. Eleven-year distribution pattern of hepatitis C virus in southern Italy. J Pathog. 2012;2012:631095.
15. Piattaforma Italiana per lo studio della Terapia delle Epatiti Virali (PITER) [Italian platform for the study of the Therapy of Viral Hepatitis (PITER)]. Available from: http://www.iss.it/piter/?lang=1\&id=163\&tipo=3. Accessed April 16, 2016. Italian.

16. Italian National Institute of Statistics. Demo: demography in figures database; 2015. Available from: http://demo.istat.it/pop2015/index.html. Accessed April 16, 2016.

17. Gardini I. Epatite $\mathrm{C}$ e sostenibilità dei farmaci innovativi [Hepatitis $\mathrm{C}$ and sustainability of innovative medicines]. Care $i$ costi dell'assistenza e risorse economiche. 2015;6:1-4. Available from: http://careonline.it/wp-content/ uploads/2015/12/Gardini_Care_6_2015.pdf. Accessed April 16, 2016. Italian.

18. Italian Ministry of Justice. Statistics: prisoners in the Italian jails, situation on the $31^{\text {st }}$ of December 2015. Available from: https://www. giustizia.it/giustizia/it/mg_1_14_1.wp?previsiousPage=mg_1_14\&co ntentId=SST1204480. Accessed April 16, 2016.

19. Regional Health Agency of Tuscany. La salute dei detenuti in Italia: i risultati di uno studio multicentrico. Documenti dell'Agenzia Regionale di Sanità della Toscana, 83 [The health of detainees in Italy: results of a multicenter study. Documents of the Regional Agency of Health of Tuscany, 83]; April 2015. Available from: https://www.ars.toscana.it/files/pubblicazioni/ Volumi/2015/carcere_2015_definitivo.pdf.Accessed April 16,2016. Italian.

20. Italian Ministry of Health, cited by adnkronos. Available from: http:// www.adnkronos.com/salute/sanita/2014/09/12/niente-ticket-sul-dellericette-per-esami-visite-arrivo-una-riforma-del-sistema_XL3hfVYler10149USc9JXN.html?refresh_ce. Accessed April 16, 2016. Italian.

21. Italian Medicines Agency (AIFA). Lista Centri autorizzati alla prescrizione dei farmaci antivirali per l'epatite C - Aggiornamento [List authorized centers to prescription antiviral drugs for hepatitis $\mathrm{C}$ - Update]; December 30, 2015. Available from: http://www.agenziafarmaco.gov.it/ it/content/lista-centri-autorizzati-alla-prescrizione-dei-farmaci-antivirali1\%E2\%80\%99epatite-c-aggiornamento-. Accessed April 16, 2016. Italian.

22. Mühlberger N, Schwarzer R, Lettmeier B, Sroczynski G, Zeuzem S, Siebert U. HCV-related burden of disease in Europe: a systematic assessment of incidence, prevalence, morbidity, and mortality. BMC Public Health. 2009;9:34.

23. McEwan P, Ward T, Webster S, Kalsekar A, Brenner M, Yuan Y. Estimating the cost-effectiveness of 12 weeks of daclatasvir+sofosbuvir in patients chronically infected with HCV genotype 3 . Poster presented at the 20th annual meeting of the International Society for Pharmacoeconomics and Outcomes Research (ISPOR), May 16-20, 2015, Philadelphia, USA. Available at: http://www.ispor.org/research_pdfs/49/ pdffiles/PIN73.pdf. Accessed June 27, 2016.

24. Thein HH, Yi Q, Dore GJ, Krahn MD. Estimation of stage-specific fibrosis progression rates in chronic hepatitis $\mathrm{C}$ virus infection: a metaanalysis and meta-regression. Hepatology. 2008;48(2):418-431.

25. Shepherd J, Jones J, Hartwell D, Davidson P, Price A, Waugh N. Interferon alpha (pegylated and non-pegylated) and ribavirin for the treatment of mild chronic hepatitis C: a systematic review and economic evaluation. Health Technol Assess. 2007;11(11):1-205.

26. Italian Medicines Agency (AIFA). Social Affairs Commission audition; November 16, 2015. Available from: http://webtv.camera.it/evento/8620. Accessed April 16, 2016.

27. Agenzia Italiana del Farmaco. Determina 12 novembre 2014. Regime di rimborsabilità e prezzo del medicinale per uso umano "Sovaldi» (sofosbuvir), autorizzata con procedura centralizzata europea dalla Commissione europea (Determina n. 1353/2014). (14A09382) (GU Serie Generale n.283) (del 5-12-2014) [Determines 12 November 2014. reimbursement and price of the medicinal products for human use "Sovaldi" (Sofosbuvir), authorized by the European centralized procedure European Commission (Determines n 1353/2014). (14A09382) (OJ Series General 283) (of 05.12.2014)]. Available from: http://www.gazzettauf ficiale.it/atto/serie_generale/caricaDettaglioAtto/originario?atto. dataPubblicazioneGazzetta=2014-12-05\&atto.codiceRedazionale $=14$ A09382\&elenco30giorni=false. Accessed April 16, 2016. Italian. 
28. Agenzia Italiana del Farmaco. Determina 8 maggio 2015. Regime di rimborsabilità e prezzo del medicinale per uso umano «Harvoni (ledipasvir/ sofosbuvir)» (Determina n. 544/2015) (15A03674) (GU Serie Generale n.109) (del 13-5-2015) [Determines May 8, 2015. Regime of eligibility and price of the medicinal products for human use "Harvoni (ledipasvir/ sofosbuvir)" (determines n 544/2015) (15A03674) (OJ General Series 109) (of 05.13.2015 )]. Available from: http://www.gazzettaufficiale.it/ eli/id/2015/05/13/15A03674/sg\%20;jsessionid=DZfS194qS9LREa1dj BOfvQ_.ntc-as1-guri2b. Accessed April 16, 2016. Italian.

29. International Monetary Fund. World Economic Outlook Database; October 2015. Available from: http://www.imf.org/external/pubs/ft/ weo/2015/02/weodata/index.aspx. Accessed April 16, 2016.

30. Società Italiana di Medicina Generale e delle Cure Primarie (SIMG), Associazione Italiana per lo Studio del Fegato (AISF), Società Italiana di Malattie Infettive e Tropicali (SIMIT). Documento intersocietario SIMG-AISF-SIMIT sul virus dell'epatite C; 2009 [InterNGO document SIMG-AISF-SIMIT on hepatitis C; 2009]. Available at: https://www.simg. it/Documenti/Rivista/2009/04_2009/4.pdf. AccessedApril 16, 2016. Italian.

31. Associazione Italiana per lo Studio del Fegato (AISF), Società Italiana di Gastroenterologia (SIGE). Programma Nazionale di Educazione e Competenza Continua, Epatocarcinoma, Corso di Formazione e di Aggiornamento Chianciano Terme (SI), 30-31 Gennaio; Febbraio 1, 2008 [Italian society of Gastroenterology (GETS). the National Education Program Competence and Continue, Hepatocellular carcinoma, Training Course and Update Chianciano Terme (SI), 30 to 31 January; February 1, 2008]. Available from: http://www.webaisf.org/media/4415/silla bus2008.pdf. Accessed April 16, 2016. Italian.

32. Associazione Italiana di Oncologia Medica (AIOM). Linee guida Epatocarcinoma. Edizione 2015 [Italian Medical Oncology Association, Hepatocellular carcinoma guidelines. 2015 edition]. Available from: https://www.aiom.it/C_Common/Download.asp?file=/\$Site\$/files/doc/ lg/2015_lg_aiom_epatocarcinoma.pdf. Accessed April 16, 2016. Italian.

33. Associazione Italiana per lo Studio del Fegato (AISF). Trapianto di fegato non urgente dell'adulto - Raccomandazioni della Commissione di Studio A.I.S.F; 2004 [Adult liver transplant not urgent - Commission Recommendations Study A.I.S.F; 2004]. Available from: http://www. webaisf.org/media/8065/documento_trapianto.pdf. Accessed April 16, 2016. Italian.

34. Italian Ministry of Health. Sistema Informativo Trapianti - Attività di donazione al; dicembre 31, 2014 [Information System Transplantation activities - the donation; December 31,2014]. Available from: http://www. trapianti.salute.gov.it/imgs/C_17_pubblicazioni_2316_allegato.pdf. Accessed April 16, 2016. Italian

35. Lawitz E, Mangia A, Wyles D, et al. Sofosbuvir for previously untreated chronic hepatitis C infection. N Engl J Med. 2013;368(20):1878-1887.

36. Lawitz E, Poordad F, Brainard DM, et al. Sofosbuvir in combination with PegIFN and ribavirin for 12 weeks provides high SVR rates in HCV-infected genotype 2 or 3 treatment-experienced patients with and without compensated cirrhosis: results from the LONESTAR-2 study. Hepatology. 2013;58:1380A.

37. Lawitz E, Lalezari JP, Hassanein T, et al. Sofosbuvir in combination with peginterferon alfa- $2 \mathrm{a}$ and ribavirin for noncirrhotic, treatment-naive patients with genotypes 1,2, and 3 hepatitis $\mathrm{C}$ infection: a randomised, double-blind, phase 2 trial. Lancet Infect Dis. 2013;13:401-408.
38. Foster GR, Pianko S, Brown A, et al. Efficacy of sofosbuvir plus ribavirin with or without peginterferon-alfa in patients with hepatitis $C$ virus genotype 3 infection and treatment-experienced patients with cirrhosis and hepatitis $\mathrm{C}$ virus genotype 2 infection. Gastroenterology. 2015;149(6):1462-1470.

39. Hézode C, Asselah T, Reddy KR, et al. Ombitasvir plus paritaprevir plus ritonavir with or without ribavirin in treatment-naive and treatment-experienced patients with genotype 4 chronic hepatitis $\mathrm{C}$ virus infection (PEARLI): a randomised, open-label trial. Lancet. 2015;385(9986):2502-2509.

40. Afdhal N, Zeuzem S, Kwo P, et al. Ledipasvir and sofosbuvir for untreated HCV genotype 1 infection. N Engl J Med. 2014;370(20):1889-1898.

41. Nelson DR, Cooper JN, Lalezari JP, et al. All-oral 12-week treatment with daclatasvir plus sofosbuvir in patients with hepatitis $C$ virus genotype 3 infection: ALLY-3 phase III study. Hepatology. 2015;61(4):1127-1135.

42. A.O.U. San Luigi Gonzaga. Affidamento della fornitura delle specialità medicinali per il trattamento dell'infezione cronica da virus $\mathrm{HCV}$, "DAKLINZA" Società Bristol-Myers Squibb s.r.l., "HARVONI" Società Gilead Sciences S.R.L., "VIEKIRAX" e "EXVIERA" Società Abbvie s.r.l. (DET. 307) (del 19-06-2015) [Supply of specialties medicines for the treatment of chronic HCV, "DAKLINZA" BristolMyers Squibb Company LTD, "HARVONI" Company Gilead Sciences S.R.L., "VIEKIRAX" and "EXVIERA" Company Abbvie LTD (DET. 307) (the 06/19/2015)]. Available from: http://www.sanluigi piemonte.it/delibere/DL33/Allegati/9781.pdf. Accessed April 16, 2016. Italian.

43. Agenzia Italiana del Farmaco. Determina 25 novembre 2011. Regime di rimborsabilità e prezzo di vendita del medicinale Pegasys (peginterferone alfa-2a) autorizzata con procedura centralizzata europea dalla Commissione europea con la decisione del 29/06/011 (Determinazione/C 2753/2011) (Gazzetta n. 285) (del 7-122011) [Determines 25 November 2011. Scheme reimbursement and price of Pegasys (peginterferon alfa-2a) authorized by the European Commission (EMA) on 29/06/011]. Available from: http://www.gazzettaufficiale. biz/atti/2011/20110285/11A15734.htm. Accessed April 16, 2016. Italian.

44. Agenzia Italiana del Farmaco. Determina 18 gennaio 2013. Regime di rimborsabilità e prezzo di vendita del medicinale per uso umano «Ribavirina Mylan» (ribavirina) autorizzata con procedura centralizzata europea dalla Commissione europea (Determina n. 38/2013) (13A00836) (GU Serie Generale n.30) (del 5-2-2013) [Regime of eligibility and price of the human use drug "Ribavirin Mylan" (ribavirin) authorized by the European Commission]. Available from: http://www.gazzettaufficiale.it/eli/id/2013/02/05/13A00836/sg. Accessed April 16, 2016. Italian.

45. Regione Calabria. Farmaci del PHT $-12^{\circ}$ Aggiornamento Tabella Prezzi - Tabelle relative al $12^{\circ}$ aggiornamento dei farmaci del PHT di cui agli Accordo-Quadro stipulati tra la Regione Calabria e le Aziende Farmaceutiche e ratificati con decreto n. 3472 (del 20-4-2015) [The PHT medication $-12^{\circ}$ Update Table Prices - Tables on the 12th update of the PHT drugs where the Framework Agreement signed between the Region of Calabria and Companies Pharmaceutical and ratified by decree n 3472 (of 04.20.2015)]. Available from: http://www.regione. calabria.it/sanita/allegati/deceti_2015/farmaci_del_pht_-12_aggiornamento_tabella_prezzi_-.pdf. Accessed April 16, 2016. Italian.
ClinicoEconomics and Outcomes Research

\section{Publish your work in this journal}

ClinicoEconomics and Outcomes Research is an international, peerreviewed open-access journal focusing on health technology assessment, pharmacoeconomics and outcomes research in the areas of diagnosis, medical devices, and clinical, surgical and pharmacological intervention. The economic impact of health policy and health systems organization also constitute important areas of coverage. The manuscript management system is completely online and includes a very quick and fair peer-review system, which is all easy to use. Visit http://www.dovepress.com/testimonials.php to read real quotes from published authors. 